\title{
AOS “CABOCLOS INOCENTES E DE BOA FÉ”: ENTRE EDUCAÇÃO E OUTRAS OBRAS DE DOM ELISEU COROLI, EM BRAGANÇA (PA), SÉCULO XX
}

\author{
Dário Benedito Rodrigues Nonato da Silva ${ }^{1}$ \\ Universidade Federal do Pará (UFPA, Campus Universitário de Bragança) \\ dario@ufpa.br \\ Leila do Socorro Rotterdan Oleto ${ }^{2}$ \\ Secretaria Municipal de Educação (SEMED, Bragança/PA) \\ leilarotterdan@yahoo.com.br \\ Romyel Dillan Cecim de Oliveira ${ }^{3}$ \\ Instituto Santa Teresinha (IST, Bragança) \\ cecimoliveira@yahoo.com.br
}

\section{RESUMO:}

Este trabalho lida com parte do desempenho de D. Eliseu Coroli, bispo católico, na cidade de Bragança (Pará, Brasil), a partir de fatos relacionados a ele como um ícone da História recente da região Bragantina, no século XX. Foi construído a partir de relatos orais e biográficos, registros escritos, imagens e relações sociais, analisando contextos e situações em torno da figura e personalidade do bispo, para compreender o perfil deste missionário religioso e seu legado para a Educação e outras atividades.

Palavras-chave: História, Educação, Bragança, século XX.

\section{TO “INNOCENT RUDE MEN WITH GOOD FAITH”: BETWEEN EDUCATION AND ANOTHER WORKS OF D. ELISEU COROLI, IN BRAGANÇA (PA), $20^{\text {th }}$ CENTURY}

ABSTRACT:

This work deals with part of the performance of D. Eliseu Coroli, catholic bishop, in Bragança city (State of Pará, Brazil), starting from facts relating him as an icon of the recent History of Bragantina's region, in the 20th century. It was built starting from oral and biographical reports, written records, images and social relationships, analyzing contexts and situations around of the illustration and bishop's personality, to comprehend the profile of this religious missionary and his legacy for the Education and other activities. Key-words: History, Education, Bragança, $20^{\text {th }}$ century.

\section{Introdução}

O italiano D. Eliseu Coroli, figura controversa ao se analisar suas obras e o impacto de suas ações no século XX, como missionário destinado à cidade de Bragança, Nordeste do Estado do Pará, foi considerado por seus contemporâneos como um "intrépido $e$ incansável arauto do Evangelho" . Depois, bispo prelado, veio a se tornar uma importante personalidade que perpassa a parte significativa da história de Bragança, não apenas por seus empreendimentos, mas pela forma como influenciou a vida da cidade. 
A pesquisa surgiu como um resultado de análise de fontes diversas, para compreender aspectos na biografia e na personalidade do religioso e teve por objetivo reunir discussões, questões e inquietações dispostas sob o olhar da História e da Educação. Ao debruçarmo-nos sobre tais fontes, notamos a possibilidade de recuperar os vestígios históricos da Educação em Bragança, confrontando registros escritos com os discursos produzidos sobre o sujeito em tela.

Numa rápida referência ao ato de pesquisa de possíveis relações sociais e políticas de Eliseu Coroli na cidade de Bragança, em eventos a ele relacionados no século XX e num conjunto variado de fontes, rapidamente muitos outros sujeitos se aglomeram nesse cenário; pessoas que mantiveram contato e realizaram iniciativas conjuntas e até mesmo paralelas às do religioso italiano e que acabam citadas no decorrer do texto.

Aqui se traz à baila a frase de Michel de Certeaus, que afirma "a História é o privilégio que é necessário recordar para não esquecer-se a si próprio”. A partir disso, existe a possibilidade de escrita da História que congregue fontes não citadas e/ou revistas anteriormente, de caráter material, ou daquelas pertencentes à memória e oralidade, além de peculiaridades que envolvem sujeitos outros, citados ou encontrados no garimpo da pesquisa, ente diversos nichos de poder que entremearam os fatos aqui referenciados.

Desta forma, as informações das fontes documentais escolhidas, dentre registros em Livros de Tombo, ofícios, registros em diários e discursos, foram recolhidas a partir do entendimento de um campo de relações de poder e de níveis culturais dos que neles estão envolvidos, tanto na sua elaboração quanto na sua divulgação e validade.

O documento não é inocente, não decorre apenas da escolha do historiador, ele próprio parcialmente determinado por sua época e seu meio; o documento é produzido consciente ou inconscientemente pelas sociedades do passado, tanto para impor uma imagem desse passado, quanto para dizer a verdade. (LE GOFF, 2004, p. 54).

O trabalho pode tornar-se dessa forma um contributo para o conhecimento da História da Educação em Bragança a partir da trajetória de um ícone local, um sujeito de um campo da memória ${ }^{6}$ e que passa, adiante, a compor também parte das temáticas competentemente trabalhadas na historiografia da Educação brasileira.

I

Nascido em Castelnuovo val Tidone, povoação da província italiana de Piacenza, em 09 de fevereiro de 1900, o quinto filho do casal de camponeses Anacleto Ludovico Coroli e Maria Molinari, Eliseu Ferdinando Coroli absorveu profundamente preceitos religiosos de sua família, especialmente de sua mãe, tanto que em tenra idade, segundo seus biógrafos, a surpreendeu com a ideia inusitada de ser missionário e sacerdote ${ }^{7}$.

No início do século XX, diversas famílias italianas cultivavam o firme desejo de possuir entre seus filhos alguns missionários que demonstrassem orgulho a seus pais, especialmente na Itália, berço da Igreja Católica, o que se coaduna à necessidade de sustento material, garantido em parte pelo ingresso de um filho numa instituição religiosa.

Após o quinto ano primário, o pai conduziu Eliseu por engano à Escola Apostólica São Bartolomeu dos Armânios, em Gênova, pertencente à Congregação dos Padres Barnabitas ${ }^{8}$, pois o seu objetivo era levá-lo a uma escola de formação diocesana e não específica. Entregou-o a essa instituição em 11 de outubro de 1911. 
Ficou interno na Escola Apostólica e cursou o equivalente ao curso ginasial, no Colégio Vittorino da Feltre ${ }^{9}$, ambos dos Padres Barnabitas. O próprio nome da escola reflete o caráter de inovação pedagógica imprimida por Feltre $(1378-1446)^{10}$, que apesar da sua formação, deixou nitidamente de orientar seus conceitos educacionais tão somente. A escola com o seu nome escolheu um programa que visava à formação integral do homem, propondo estudos onde já constava a educação física, artística, moral, estética e intelectual.

Foi uma das primeiras escolas particulares da Itália de orientação laica. Tal orientação perpassava também pela preocupação de não obrigar as crianças a estudarem contra vontade aquilo que não lhes agradava por inclinação, de outro, havia a renúncia em educar, ou ainda uma subestimação da força da educação ${ }^{11}$.

Todavia, com a forte autoridade das congregações religiosas católicas, a tarefa de adaptar o indivíduo à sociedade, acabava cultivando no aluno uma atitude de recepção ao saber instituído ${ }^{12}$. Essa teoria e prática espalharam-se pelo mundo e propunham uma mudança educacional voltada ao desenvolvimento da personalidade integral do aluno que lhe despertava a participação ativa no processo de aprendizagem.

Após concluir os cinco anos de Ginásio na Escola Apostólica de São Bartolomeu, Eliseu pediu aos pais permissão para entrar no noviciado em Monza, passando o ano em provas e, em seguida, admitido à profissão dos votos perpétuos em 22 de novembro de 1916. Conforme citações de sua biografia, este foi o último ano em que a Igreja Católica concedeu fazer-se a profissão perpétua nesta idade, aos 16 anos.

Nesta idade, em uma visita à família, Eliseu conheceu o livro Conselhos $e$ Lembranças $^{13}$, com os pensamentos de Santa Teresinha ${ }^{14}$, que se tornaria mais tarde o seu principal modelo de espiritualidade. Imitando a santa francesa, a partir deste conhecimento e da obstinação contra os pecados, criou um método particular de registros em um caderno, acerca de seus propósitos pessoais, pensamentos, afetos e desejos ${ }^{15}$.

Figura 01: O jovem Eliseu Ferdinando Coroli.

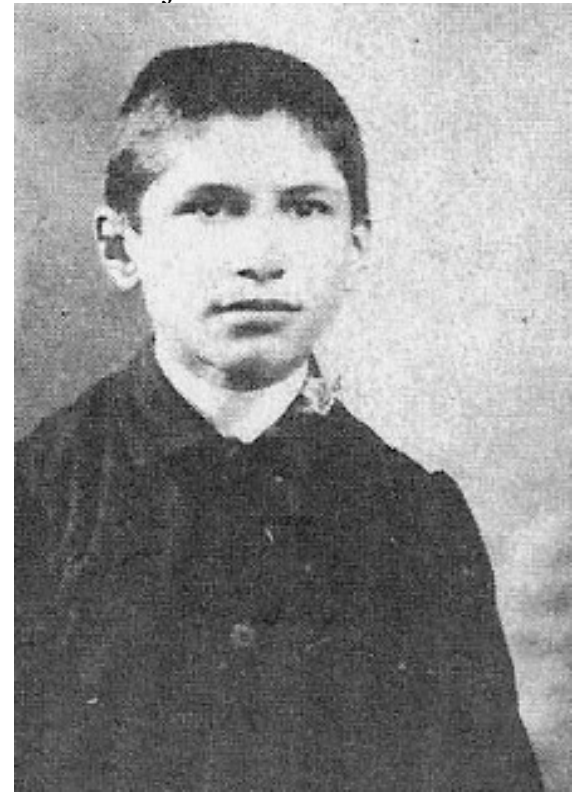

Fonte: Acervo do Instituto Santa Teresinha (Bragança/PA).

Nas suas anotações pessoais, Eliseu escreveu sobre o significado da Escola Apostólica $^{16}$, um lugar de aprendizado profundo e rigoroso, mas cheio de alegria e prosperidade. Destinado a Lodi para fazer o curso no Liceu Clássico dos Barnabitas, equivalente ao $2^{\circ}$ Grau à época, teve que interrompê-lo para servir ao Exército a partir de Revista HISTEDBR On-line, Campinas, n.48, p. 93-118 Dez.2012 - ISSN: 1676-2584 95 
21 de abril de 1918, deslocado para a localidade de Novara, onde serviu como soldado do Exército italiano no departamento sanitário.

Segundo Colares ${ }^{17}$, terminada o conflito em 1919, Eliseu continuou com seus estudos e conseguiu a maturidade clássica (equivalente ao vestibular atual) em junho de 1920 no Liceu, de Pietro Verri, em Lodi, seguindo para Roma onde ingressaria no Estudantado. Em seguida, foi ordenado sacerdote em 15 de março de 1924, dispondo-se às missões, no que foi logo atendido por seus superiores e destinado ao Brasil para o Colégio dos Barnabitas, na cidade do Rio de Janeiro. Realizava, assim, o desejo de ser missionário além-fronteiras e juntar-se aos Padres Barnabitas que já atuavam no Brasil desde $1904^{18}$.

Chegou ao Porto de Santos em 22 de dezembro de 1924 e apresentou-se a seu superior no Colégio Zacarias, no dia 24, na Rua do Catete, 113, onde permaneceu como Vigário (pároco) coadjutor na Paróquia de Nossa Senhora de Lorêto, em Jacarepaguá, subúrbio da capital federal, assim como em atendimento a capelas distantes. Sendo o mais novo naquela comunidade, transparecia grande vitalidade e ânsia pela missão assumida em terras estrangeiras, pois "por aqueles trabalhos coadjutorias, mostrou que seria capaz de empreendimentos de máxima envergadura”, como declarou para a Ir. Terezinha Colares, o Pe. José Meireles Sisnando, um de seus alunos em Jacarepaguá e contemporâneo de Eliseu $^{19}$. Ficou no Rio de Janeiro, por cinco anos, trabalhando no Colégio Apostólico.

Figura 02: Eliseu Coroli (o último em pé, à direita) e padres Barnabitas, em viagem ao Brasil.

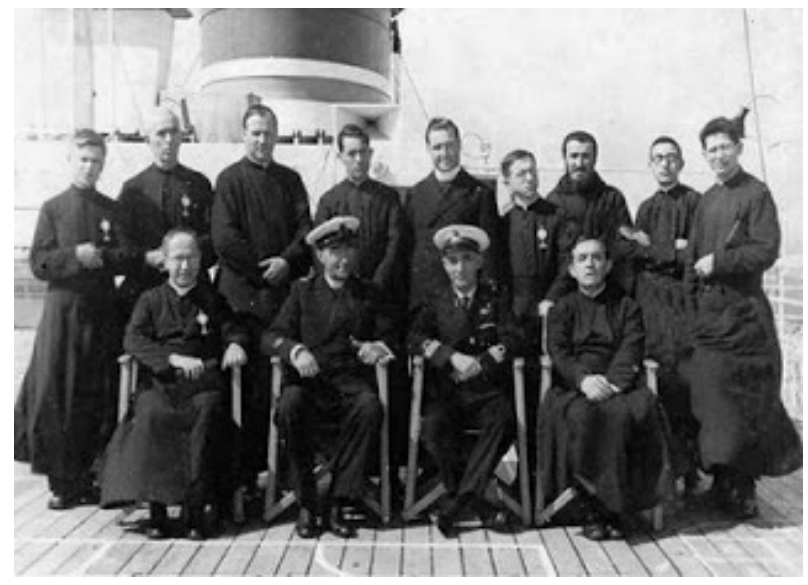

Fonte: Acervo do Instituto Santa Teresinha (Bragança/PA).

Em 14 de abril de 1928, o Papa Pio XI, através da bula Romanus Pontifex, erigiu a Prelazia de Nossa Senhora da Conceição do Gurupi ${ }^{20}$, confiando-a à administração dos Padres Barnabitas, com seu território desmembrado da Arquidiocese de Belém, capital do Pará. Era um projeto de expansão, descentralização e controle por que passava a extensa área arquidiocesana que enfrentava problemas com escassez de sacerdotes. Mas a cidade de Bragança ainda não era parte dessa área.

Interinamente, até a sua chegada ao território da recém-organizada prelazia, o Arcebispo de Belém do Pará, D. João Irineu Jofylli, assumiu a administração da nova área de evangelização. Depois, Pe. Eliseu Coroli e mais três outros sacerdotes - Pe. Leopoldo Gerosa, Pe. Roque Carenzi e Pe. Ângelo Moretti - foram incumbidos de vir ao Pará onde se estabelece em 22 de dezembro de 1929.

O Administrador Apostólico Francisco Richard e esses quatro sacerdotes barnabitas chegaram à cidade de Ourém (Pará) na tarde de 05 de janeiro e no dia seguinte assumiram o controle da então Prelazia do Guamá no Dia dos Reis, 06 de janeiro de 1930, numa missa 
solene com maciça participação da comunidade, onde leu a bula de tomada de posse da prelazia. Registros de tombo prelatício contam que, no interior de Ourém, por exemplo, Eliseu chegou a cumprir mais de duzentos e oitenta dias em desobriga sem retornar a sede.

As distâncias impuseram grandes dificuldades aos missionários, pelo transporte de pessoas e cargas feito somente por via fluvial através do rio Guamá e pela via férrea da extinta Estrada de Ferro de Bragança-Belém, localizada na Região Bragantina. Disso resultou o pedido de Richard ao Núncio Apostólico no Brasil de que a Paróquia de Nossa Senhora do Rosário (Bragança) fosse anexada à Prelazia do Guamá para facilitar a sua administração, o que acabou se confirmando em 1934. Daí, o Pe. Francisco Richard transferiu a sede para Bragança, assumindo o vicariato da cidade juntamente com o Pe. Eliseu Coroli.

Eis as circunstâncias históricas mais gerais do início do trabalho pastorais do Pe. Eliseu Coroli, iniciado na região do rio Guamá e que almejava uma formação cristã adequada aos regulamentos da Congregação dos Padres Barnabitas, nicho espiritual e moral onde o próprio Pe. Eliseu compreendeu a responsabilidade de continuar a faceta histórica desta ordem religiosa em terras de missão, como que ensaiando os labores e os sacrifícios que teria de enfrentar anos mais tarde.

O padre vira e revira todos os igarapés destas freguesias: mas é custoso edificar onde não há base. Enquanto não houve padres fixos nesta matriz, todos a uma voz pediam a presença deles, demonstrando o maior interesse pela religião. Quando os padres chegaram, encontraram os cristãos de São Miguel na maior indiferença religiosa. Mal e mal apareceram os meninos e as meninas à missa dos primeiros domingos. $\mathrm{O}$ número foi diminuindo cada vez mais, até se reduzir, às vezes, a uma dúzia e até menos. A freqüência dos adultos à missa, nos domingos, nunca foi grande. Ficou, mais ou menos, sob umas 20 pessoas presentes ao Santo Sacrifício dominical ${ }^{21}$.

No cenário encontrado pelos padres figurava ainda o analfabetismo, a indiferença religiosa ao catolicismo, a dispersão da população e, principalmente, a falta de catequistas idôneos, portanto, o início de suas atividades era um desafio, para o qual organização e estratégia foram fundamentais. Isso gerou também desgastes físicos, como os do padre barnabita Francisco Richard, que debilitado após trinta anos de trabalho, retirou-se da administração apostólica de tão extensa prelazia, exultando com a escolha de seu mais fiel colaborador, Pe. Eliseu Coroli ${ }^{22}$ para continuar a empreita religiosa da ordem.

Assim, "as três [sic] direções encetadas por Dom Eliseu (a catequese, a educação escolar, a assistência hospitalar e a evangelização dos índios) ${ }^{23}$ " estavam um tanto definidas no projeto dos missionários, cujo "[...] ideal é a instrução daquelas crianças abandonadas pela civilização e condenadas à miséria, ao impaludismo, ao completo alheamento da Pátria ${ }^{24}$ ". Estas direções "não poderiam ser continuadas sem que houvesse um espaldar com a participação das forças locais, que trabalhassem junto aos missionários ${ }^{25}$,, como um apoio para os intentos desses padres, recuperando também requícios de uma Romanização ${ }^{26}$ tardia, no século XX.

Todas essas circunstâncias coletivas tiveram no caráter de Pe. Eliseu Coroli uma grande repercussão, até mesmo porque ele trabalhou de forma a ampliar sua influência - a religiosa - num contexto social, cultural e político da época, o que encontramos nos registros escritos do padre. Não cabe apenas dar atenção à formação acadêmica, moral e religiosa de Eliseu Coroli, mas necessário levar em conta que, ao trabalhar com esses relatos oriundos dos livros de tombo, nos deparamos com um homem, branco, europeu, 
cristão, sacerdote e que se considerava apto para fornecer a salvação num contexto tido como exótico, inferior e selvagem, como a Amazônia.

Ademais, cabe considerar a questão da experiência e da cultura ${ }^{27}$ vivida por nosso sujeito principal, usando os aportes metodológicos da História Social. Essa recuperação do passado, na multiplicidade de experiências, é uma tentativa de rememorar a importância da posição social do sujeito, seus valores e atitudes. Elas se transformaram em instrumentos de compreensão dos outros cenários, com diversos sujeitos históricos relacionados e que, não podem ser esquecidas ou abandonadas diante do vasto legado de Eliseu Coroli existente em Bragança. Talvez, como descobrir como o passado e o presente estão se relacionando, apoiados em Jacques Le Goff, quando disse:

Toda história é bem contemporânea, na medida em que o passado é aprendido no presente e responde, portanto, aos seus interesses, o que não é só inevitável, como legítimo. Pois que a história é duração, o passado é ao mesmo tempo passado e presente ${ }^{28}$.

Por tudo isso, se revela uma memória histórica do sujeito e, por isso, é compreensível que fixemos o olhar na experiência cultural. A cultura tornou-se um conceito mais concreto e utilizável, "localizado dentro de um equilíbrio particular, de relações sociais, um ambiente de trabalho de exploração e resistência à exploração, de relações de poder mascaradas pelos ritos do paternalismo e da deferência" ${ }^{29}$.

Figura 03: D. Eliseu Maria Coroli, aos 80 anos.

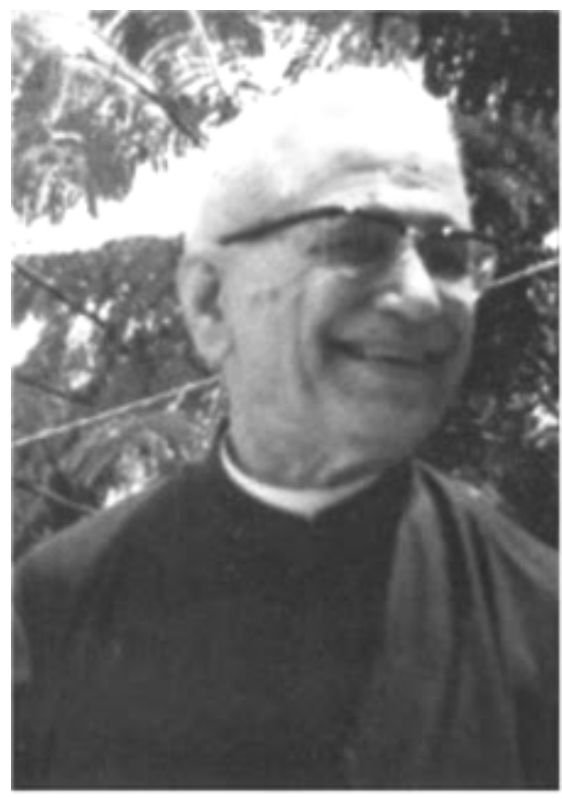

Fonte: Acervo do Instituto Santa Teresinha (Bragança/PA).

II

Ao passo de todas as dificuldades encontradas, Pe. Eliseu passou a considerar a formação de professoras e catequistas como pressuposto fundamental de sua ação, procurando moças que o auxiliariam no trabalho educativo, estratégia facilitada por barganhas e por sua autoridade religiosa junto às famílias bragantinas. 
Em 03 de fevereiro de 1934, um decreto consistorial anexou definitivamente mais três paróquias à prelazia -São Miguel do Guamá, São Domingos do Capim e Santana do Capim - e o encarregado dos trabalhos, Mons. Richard, nomeou o Pe. Eliseu como responsável pelas paróquias. Este decreto alterou o nome, a sede e a padroeira da prelazia, passando a se chamar Prelazia de Nossa Senhora do Rosário do Guamá, sediada em Bragança, cidade já anexada ao seu território.

Nos escritos biográficos de Eliseu Coroli, feitos por uma religiosa da congregação por ele fundada, Ir. Terezinha Colares ${ }^{30}$, consta que em 30 de junho de 1937, numa viagem à Itália, mesmo doente e em companhia do também sacerdote Idelfonso Maria Clerici, Pe. Eliseu visitou a Madre Geral das Irmãs do Preciosíssimo Sangue. Na conversa, abordou a real situação da prelazia, percebendo o interesse e a simpatia demonstrado ao projeto pela madre, que conseguiria religiosas para auxiliá-lo.

No dia 9 de dezembro do mesmo ano, a Santa Sé nomeou o Pe. Eliseu Maria Coroli como Administrador Apostólico da Prelazia de Nossa Senhora do Rosário do Guamá ${ }^{31}$, cargo em que tomou posse no dia 30 de dezembro do mesmo ano. Nesse mesmo período, procurou seus superiores expondo a intenção de trazer para a Amazônia as Irmãs do Preciosíssimo Sangue com o objetivo de torná-las contribuintes em seus projetos, já que

seriam estas religiosas-mães e mestras, "mulheres de trabalho e oração, como tão bem conhecemos - as primeiras educadoras das jovens caboclas que, formadas na sede principal da missão, daí voltariam para suas vilas'. (MERCÊS, 1984. p. 3)

Em 1938, Coroli conseguiu a autorização e o envio de cinco freiras para a missão em Bragança, que chegam com ele no dia 12 de agosto, sendo recebidos com festa pela população ${ }^{32}$. Essas colaboradoras se ocupariam das gremistas (aspirantes à vida religiosa), dos doentes, com os estudos da Língua Portuguesa, em trabalhos domésticos e aulas de pintura e bordado com três ou quatro alunas internas.

Os trabalhos do missionário ganhou um novo impulso e seus objetivos alargaram-se junto com as intenções dos padres Barnabitas. Eliseu deixou sobre esse período diversos registros, tão bem conservados e num envolvente mistério, que aumenta e atiça a curiosidade de muitos ainda hoje. Ficamos muito com os relatos orais, recolhidos no tempo presente em torno da sua figura, com entrevistas que o descreveram como pioneiro e como apóstolo da religiosidade e da educação nessas terras paraenses.

Dom Eliseu se tornou um sujeito que construiu uma memória recorrente nos diversos relatos de seus contemporâneos. Essa importante inserção no estudo da memória e suas marcas na coletividade, ainda carece de dados, uma vez que ainda não estão disponíveis tantos documentos que dispõem sobre esses fatos e, para dar conta de uma explicação mais próxima da realidade, recorremos a Peter Burke que diz:

Quando não se dispuser delas, tem-se de tolerar a segunda escolha, buscando-se as informações longe de fonte pura do texto oficial. Os dados orais não, nesses termos, certamente a segunda melhor ou pior escolha, pois seu papel é facilitar as histórias de segunda escolha sobre as comunidades com fontes escassas ${ }^{33}$.

Sua relação com o poder estabelecido se deu de forma respeitosa e conveniente, já que seus discursos de implantação de uma nova lógica de civilização, circunscrita não somente ao ambiente religioso, fato perceptível quando da análise documental. $\mathrm{O}$ relacionamento entre a Igreja a Prefeitura se deu de forma cordial, já que se pretendia 
elevar o nível cultural do município a partir de novos empreendimentos, tendo na Educação um poderoso vetor.

Segundo o Pe. José Ramos das Mercês, no artigo Barnabitas 450 anos $^{34}$, os trabalhos dos Barnabitas "não poderiam ser continuados sem que houvesse um espaldar com a participação das forças locais, que trabalhassem junto aos missionários".

Um desses documentos traz as impressões acerca da influência do Pe. Eliseu Coroli, no Relatório do Exercício de 1939, à pagina 49, do prefeito Augusto Corrêa, tratando do relacionamento entre a Prefeitura e a Prelazia do Guamá, no item "Religião".

CATÓLICA - Esta cidade é sede da Prelazia do Guamá. (...) A prelazia tem por administrador apostólico Monsenhor Elizeu Corolli. (...) Mantemos as melhores relações com Monsenhor Eliseu Corolli, que se tem mostrado um esforçado pelas causas do ensino e da religião, auxiliando-o dentro das possibilidades do município.

É possível demonstrar um contraste entre essa memória e a documentação oficial, a partir dos trabalhos do insigne professor e folclorista Armando Bordallo da Silva ${ }^{35}$, que demonstrou e levantou dados de que existia uma cidade com um intenso teor cultural entre seus habitantes, ricos ou pobres, leigos ou padres, outra visão sobre Bragança, fruto de interessantes levantamentos etnográficos ${ }^{36}$.

III

Os padres Barnabitas que trabalhavam em Bragança residiam na antiga residência do cônego Miguel Joaquim Fernandes, falecido em $1904^{37^{3}}$, que a deixou de herança para a arquidiocese. Quando da vinda dos outros padres, o arcebispo doou o prédio para esta congregação, com um propósito de que não se desfizessem do prédio ou modificassem sua finalidade de moradia.

Essa casa serviu de abrigo às primeira Irmãs Preciosinas que vieram para a cidade com Eliseu Coroli em 1938. Os padres Barnabitas se mudaram para outro lugar, menos confortável, uma casa localizada no quadrilátero onde hoje está o Instituto Santa Teresinha e que funcionou como um posto dos Correios na cidade ${ }^{38}$.

Por intermédio do Prefeito Municipal à época, Augusto Corrêa, do Juiz de Direito e de seus propósitos pessoais, Pe. Eliseu tomou à frente a fundação de uma Escola Normal apenas três meses depois de voltar da Itália. Ele visitou o Interventor Federal no Pará, José Carneiro da Gama Malcher, solicitando a equiparação dos cursos Primário e Normal da escola que ainda iria fundar com os da Escola Normal do Estado ${ }^{39}$, obtendo resposta positiva mesmo sem todo o atendimento às exigências da época para fazer funcionar a escola $^{40}$. O interventor não só deu seu aval como providenciou junto a assessores, de forma gratuita, a documentação para a equiparação do Colégio. 
Figura 04: Prédio (à esquerda) onde funcionou o Instituto Santa Teresinha, em Bragança.

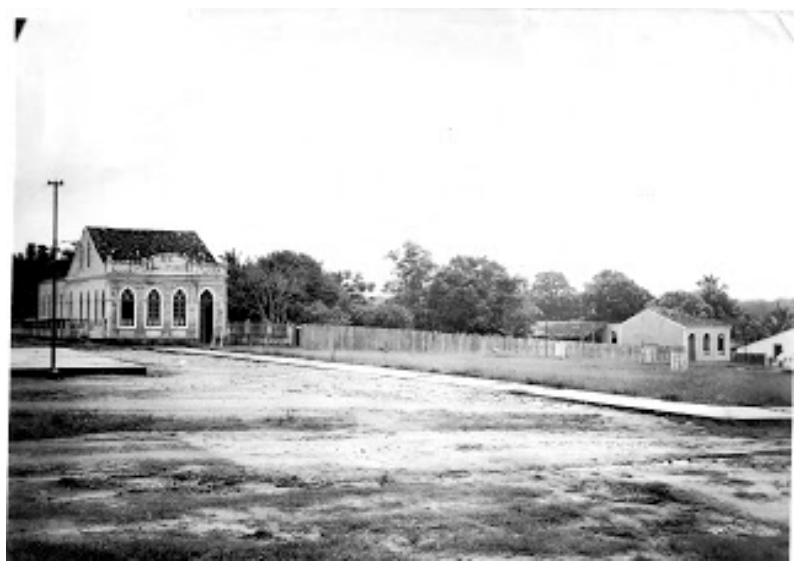

Fonte: Acervo do Instituto Santa Teresinha (Bragança/PA).

No dia 23 de novembro de 1938, o Sr. José Carneiro da Gama Malcher assinou o decreto de equiparação à condição de Escola Normal do Colégio Santa Teresinha, notícia festivamente recebida pelos senhores bragantinos mais abastados, que antes enviavam seus filhos para a capital do Estado a fim de continuarem sua formação intelectual.

Em janeiro de 1939, Eliseu Coroli comprou a casa da Sra. Francisca Alcântara, situada em frente à Praça da Matriz (hoje Catedral de Nossa Senhora do Rosário), por 800 contos de réis e em fevereiro "realizou-se a primeira prova de exame de admissão do nosso curso Normal, com vinte candidatos, sendo dezesseis moças, três rapazes e uma irmã”, conforme relata a Ir. Terezinha Colares em seu excerto Os Cinquenta Anos do Instituto Santa Teresinha, de 1988. As aulas iniciaram em fevereiro de 1939, com 18 meninas e 1 menino.

Foi, decisivamente, uma contribuição à Educação nesta região da Amazônia, permitindo a educação de uma vasta prole de meninos e meninas bragantinos e do interior $^{41}$, sendo o Colégio Santa Teresinha a terceira Escola Normal do Pará, depois das escolas da capital Belém e de Santarém.

Em seguida à equiparação, Eliseu começou a comprar móveis, utensílios e materiais para o funcionamento da escola, visando atender uma vasta clientela da região. Para isso, ele logo organizou um internato. De acordo com COLARES (1988. p. 5.) "no dia onze de dezembro de 1938, o jornal 'O Bragantino', publicava a primeira página, referindo-se ao decreto de fundação do colégio", que a cidade tinha mais um importante melhoramento.

O nome do Colégio não só homenageava a padroeira das Missões, mas expressava a sua fidelidade, ao confiar à intercessão da santa francesa, todos os trabalhos, chegando a constituí-la ecônoma - ou tesoureira - do colégio, o que levou Pe. Eliseu a acreditar que a obra fosse concluída por intermédio de graças provindas da fé.

Percebemos a grande organização desses padres, por sua formação e pela obediência aos desígnios internos de sua congregação. A tudo relatavam com uma invejável precisão e riqueza de detalhes, como na fundação do colégio, onde estava presente um forte simbolismo na formação dos alunos, como narrou o próprio Eliseu.

Jesus Menino sorri sobretudo a todas as crianças... Ao lado do Menino Jesus, portanto, no Menino Jesus eu vejo todos os milhares dos meus... ou 
melhor dos nossos meninos... São crianças brancas, são amarelinhas, são escuras, são negras, são de todas as cores, de todos os matizes sepultadas no fundo das matas... Diante do presépio de Jesus Menino não se pode deixar de amá-las, de fazer todos o sacrifícios para a salvação das suas alminhas. ${ }^{42}$

As professoras do curso primário e primeiras colaboradoras diretas de Monsenhor Eliseu, no Colégio Santa Teresinha, foram Theodomira Raimunda da Silva Lima e Isabel Ribeiro de Almeida, professoras que vieram para Bragança com suas famílias, lembradas em Bragança pela disciplina e rigor técnico. Por um lado, as professoras acreditavam no projeto educativo do religioso, dedicando-lhe tempo, trabalho e acompanhamento dos alunos. De outro, com a confiança de Coroli em se apoiar nos serviços de professoras leigas, colaboradoras na organização daquele ano escolar e na parceria obtida para que sua obra fosse levada adiante, até que a finalidade primordial do seu colégio se completasse: "preparar jovens, que levando uma vida consagrada a Deus, ajudassem na evangelização de sua terra" 43 .

Em $1^{\circ}$ de dezembro de 1939, uma reunião dos Padres Barnabitas consultores da Prelazia decidiu pela edificação do prédio para abrigar o colégio ${ }^{44}$. Eliseu Coroli encontrou na sua congregação de origem, a dos Clérigos Regulares de São Paulo ou Barnabitas, o apoio para a construção de um prédio específico para o Colégio Santa Teresinha, firmando um convênio escrito que em seu primeiro item especificava que

a Prelazia do Guamá concede à Congregação dos Clérigos Regulares de São Paulo Apóstolo (Barnabitas) e faculdade de construir com suas despesas e em sua propriedade, um Colégio, na cidade de Bragança ${ }^{45}$.

Para um empreendimento desta envergadura, Coroli comprou terrenos próximos ao quadrilátero onde está situado atualmente o Instituto Santa Teresinha, entre a Praça das Bandeiras à frente, Travessa Padre Gerosa por trás, Avenida Nazeazeno Ferreira (antiga Rua da Liberdade) à direita e Rua 13 de maio à esquerda, no centro urbano de Bragança. Buscou apoio na sociedade bragantina, pelo seu conhecimento e entrosamento social e político. Até nos recolhimentos de esmolas e ofertas das igrejas, onde porventura estivesse celebrando missas fora do Estado, organizaram-se doações para a construção do prédio ${ }^{46}$.

A obstinação de Coroli foi tamanha a ponto de remeter ao Ministério de Educação e Saúde Pública os relatórios quantitativos e qualitativos de atividades e de resultados, em nome da Prelazia do Guamá, então órgão mantenedor do Colégio Santa Teresinha, chamando atenção ao modelo disciplinar que estava em vigor no país. Seus relatórios podem se constituir como provas de um trabalho ordeiro e obediente às normas legais impostas com o Estado Novo.

É importante salientar, aqui, as orientações emanadas da Pastoral Coletiva dos Arcebispos e Bispos das Províncias meridionais do Brasil, datada de 1915, resultado de diversas conferências episcopais e relevante documento para a Igreja, depois apresentadas sob o título de Constituições Diocesanas das Províncias Meridionais do Brasil, ou simplesmente, Constituições Eclesiásticas. O documento determinava categoricamente que fosse instalado, segundo a conveniência de cada diocese (neste caso, prelazia) e seu bispo, um seminário ou um colégio em que pudessem educar para o sacerdócio um determinado número de jovens, de acordo com as possibilidades ${ }^{47}$.

Sagrado bispo em 13 de outubro de 1940, D. Eliseu já contabilizava inúmeras viagens ao interior da prelazia, inclusive aos índios da região, além da parceria com o poder público local e ações de evangelização que fazem parte da sua memória, como Revista HISTEDBR On-line, Campinas, n.48, p. 93-118 Dez.2012 - ISSN: 1676-2584 102 
sacerdote e administrador, especialmente pela constituição de sua principal obra religiosa: a Congregação (sociedade e depois instituto) das Irmãs Missionárias de Santa Teresinha.

O lançamento da pedra fundamental do Instituto Santa Teresinha foi realizado numa pomposa e participada celebração no dia 05 de julho de $1940^{48}$.

Figura 05: Benção e lançamento da pedra fundamental do Instituto Santa Teresinha, em 1940.

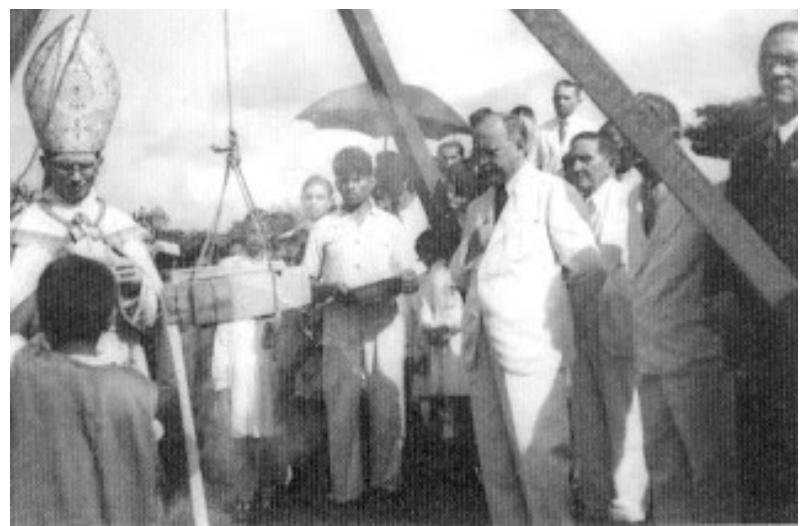

Fonte: Acervo do Instituto Santa Teresinha (Bragança/PA).

É bastante interessante o relato do já bispo D. Eliseu Coroli, enviado como carta à Itália, possivelmente em agosto ou setembro de 1940.

Devemos confessar que foi uma coisa muito solene. No mesmo dia festejamos o IV Centenário da morte do nosso santo pai. Por disposição do prefeito da cidade, o comércio ficou fechado até às 9 horas, afim de que todos pudessem participar das funções. A festa foi muito animada. Às 6 e meia saía da Igreja paroquial uma bonita procissão, composta pelas Associações Religiosas e confrarias. O Apostolado da Oração levava a imagem de Sagrado Coração de Jesus, os jovens da Ação Católica do Colégio levavam a imagem de Santo Antonio Maria Zacaria e as crianças do colégio, a de Santa Teresinha ${ }^{49}$.

Entretanto, a rigidez no ensino e na doutrina existente no Colégio Santa Teresinha foi atenuada com elementos novos. Eles seriam as diversões permitidas e entendidas como salutares, de onde se destacaram as peças teatrais, apresentadas em diversas ocasiões a um público externo ao colégio, como autoridades. Era conhecido o apreço do bispo pelo teatro, não menor à música, conforme seus contemporâneos.

Podemos perceber que, desde a inauguração do colégio, o discurso utilizado pelo bispo Coroli sempre foi conduzido pela valorização da educação cristã como sustentáculo da sociedade e a formação de catequistas como um embasamento da fé católica, de forma a atingir a juventude com os preceitos católicos e morais inseridos no contexto educacional, evidentemente relacionado aos condicionantes sociais, políticos e econômicos. Assim, para D. Eliseu, se a educação não estivesse baseada em moldes da moral cristã, a formação de homens e mulheres úteis à família e à sociedade estaria comprometida.

A juventude seria, portanto, uma força que poderia ser facilmente aproveitada para o bem da religião. E, segundo o pensamento desse prelado, o modo adequado para essa juventude contribuir para a religião seria incentivá-la na prática de princípios sãos, aos sentimentos elevados da piedade, à noção do dever e ao respeito para com os superiores civis ou religiosos ${ }^{50}$, em torno de uma sutil intransigência. 
Desse modo, é possível apresentar um perfil do professor e do educador Eliseu Coroli como o responsável pela condução dessa formação: o trabalho, pois, do educador, não era outro senão o de vigiar as más tendências, tentar corrigi-las com meios mais adequados e até brandos já ao primeiro despontar assim como incentivar bons propósitos, estimulando os alunos ainda jovens para as práticas virtuosas e para o trabalho.

Talvez a característica mais marcante para seus contemporâneos, pelo menos nos relatos orais, seja a manutenção de um sorriso constante, muito peculiar e que encantava a todos os que o acompanhavam ou por ele eram acompanhados no Colégio Santa Teresinha.

Situam-se dois elementos simbólicos fundamentais da identidade ${ }^{51}$ do educador em questão: o sorriso e a formação integral. Em relação a isso, no monumental conjunto dos quadros de formatura, elevados na sala de entrada principal, no segundo pavilhão do Instituto Santa Teresinha, se pode ler "Semear a alegria" (1943) e "Ensinar para alegrar" $(1948)^{52}$ junto à filosofia da escola por ele anunciada de que "Educar é não somente instruir. Instruir bem e preparar para a vida".

Nem todos os professores e colaboradores da época, sendo padres ou freiras, possuíam esse mesmo espírito, mas foi ele, como idealizador do colégio, quem traçou e escreveu as normas da escola, exigindo metodicamente de todos os seus auxiliares na educação, uma postura de bom professor, ao menos para a época. A concepção de ensinar sai da dimensão da ação e da interlocução e passou ao plano da pregação, da catequização como numa espécie de abnegação, de uma missão apostólica.

O bispo Eliseu Coroli procurou legitimar sua ação educacional através das relações com o poder, de certo ponto, de maneira austera enquanto agente de poder, impondo sua maneira de conceber e de ver o mundo, especialmente junto à classe média da sociedade bragantina ${ }^{53}$.

Um fato é marcante na década de 40 e que marcou Eliseu Coroli: a questão da posse do Colégio Santa Teresinha pelos militares no período da II Guerra Mundial. Segundo os documentos encontrados e correspondências, em 07 de outubro de 1942, Eliseu escreveu aos seus padres de origem italiana sobre o estado de alerta que o envolvia, recomendando prudência e colaboração com as autoridades brasileiras, já que estavam rompidas as relações diplomáticas entre o Brasil, a Itália e a Alemanha.

O Brasil está em guerra, cumpre-nos cooperar com as autoridades legitimamente constituídas; $\mathrm{O}$ momento atual é delicado também por outras circunstâncias: os inimigos de nossa religião estão de atalaia, espreitando qualquer pretexto para insinuar as mais absurdas calúnias.

Ele os recrutou na observância às leis brasileiras e no seu fiel cumprimento, como proteção individual e avisou do perigo da campanha da imprensa brasileira contra os padres de outra nacionalidade em especial italianos e alemães, e do sério risco de que esses padres fossem transferidos para a capital do Estado.

Com uma riqueza impressionante de detalhes em seus escritos, hoje em uma documentação diversificada em cartas, ofícios, anotações pessoais e anotações religiosas, Eliseu deixou um valioso registro quando a questão da tomada do Instituto Santa Teresinha pelo Exército, ao dizer que "perdemos o nosso Colégio, mas não perdemos a nossa alegria e nem a nossa paz. Vamos construir outro" 54.

Em 22 de novembro de 1942, uma comissão liderada pelo Mj. Luís Pires de Camargo e pelo Cap. Dias Neves visitou o prédio do Colégio Santa Teresinha ainda em construção, levado pelo prefeito Augusto Corrêa, considerando-o adequado para a 
instalação de uma unidade militar ${ }^{55}$ e solicitando ainda que a residência dos padres servisse de moradia para as autoridades do Exército que passariam a morar em Bragança.

No final de dezembro de 1942, Eliseu foi chamado à Belém pelo Cel. Euclides Zenóbio da Costa, comandante da $8^{\text {a }}$ Região Militar, que exigiu a cessão do prédio do Colégio em construção pelo valor total de seiscentos e vinte mil cruzeiros, ficando para a prelazia a finalização da obra.

É interessante que nesse sentido, o general fez o bispo compreender que não estava disposto a discutir a questão, deixando claro que tinha outros meios para resolver o impasse caso Coroli não cedesse o Colégio. Eliseu ouviu as opiniões de padres como Paulo Beloli e Afonso di Giorgio, além do engenheiro Cláudio Chaves sobre a questão, aceitando depois a proposta de venda e de assumir o término da construção ${ }^{56}$.

Em janeiro de 1943, o primeiro contingente do $35^{\circ}$ Batalhão de Caçadores ocupou o Colégio em construção e o seu quintal. A saída apontada pelos padres era a de construir um novo prédio que serviria a fins educacionais do Instituto Santa Teresinha, no terreno ao lado da Igreja Matriz Nossa Senhora do Rosário ou nos fundos do prédio tomado. As aulas daquele ano, iniciadas em $1^{\circ}$ de fevereiro de 1943, se deram numa casa alugada por trezentos cruzeiros junto ao Sr. Abraão Moisés, em frente à então Matriz.

Em 21 de fevereiro de 1943, D. Eliseu foi notificado da nomeação de Joaquim Magalhães Cardoso Barata como interventor federal em substituição a José da Carneiro da Gama Malcher. O prefeito eleito era Joaquim Lobão da Silveira, que era professor do colégio e que assumiria o cargo em substituição a Augusto Corrêa.

Esse fato deu início a uma mobilização popular, conforme o texto de um telegrama dos bragantinos ao interventor federal, com trezentas assinaturas, pedindo a devolução do prédio do colégio à Prelazia. Com a chegada de um novo comandante para o batalhão em Bragança, Francisco de Paula Cidade, em 03 de junho de 1943, D. Eliseu participou da recepção ao general, com saudação feita por uma aluna do Colégio e um desfile de alunos. A Prefeitura ofereceu um banquete de acolhida ao general, que visitou o prédio e dirigiu uma fala às Irmãs Preciosinas e às alunas, sem referir-se à questão do prédio, um grande problema a ser resolvido.

Nesse ínterim, o Ministro da Guerra, Gen. Eurico Gaspar Dutra, enviou ofício ao comandante da $8^{\text {a }}$ Região Militar, autorizando-o a desfazer os atos da desapropriação do imóvel. A negociação duraria ainda mais um ano, até que em 29 de dezembro de 1943, Coroli recebeu a proposta do comandante oferecendo a devolução do prédio mediante o pagamento integral de trezentos mil cruzeiros, quantia providenciada por Eliseu.

Somente em 04 de março de 1944, D. Eliseu e o Pe. Luís Gonzaga Freire de Almeida, diretor do Colégio Santa Teresinha, foram recebidos no quartel pelo Gen Francisco de Paula Cidade, quando o bispo entregou ao general a quantia recebida do Exército para a conclusão da obra e que asseguraria novamente a posse do prédio à Prelazia. Vinte dias depois, um decreto presidencial de Getúlio Vargas anulou a desapropriação do prédio, onde permaneceram ainda cerca de trezentos soldados e que só se retiraram de Bragança em 16 de fevereiro de 1945, ao final do conflito mundial ${ }^{57}$.

A notícia da inauguração do prédio do Instituto Santa Teresinha veio no convite de formatura da primeira turma de Normalistas, de janeiro de 1944. Segundo Bolívar Bordallo da Silva, o edifício era um prédio "de 3 pavimentos, de construção sólida e estilo gótico, com capacidade para 300 alunos" $"$. Nesse sentido, Eliseu foi decisivamente atuante ao estimular uma formação escolar ligada nos preceitos do Estado brasileiro e de congregação religiosa missionária em região de missão além-fronteiras, afirmando seus empreendimentos como o Instituto Santa Teresinha. 
A cidadania, pleno exercício de direitos e deveres, como se concebe, se enquadrava até mesmo no lema de seu Instituto - "por Deus e pela Pátria" - para ajudar a todos na reflexão, como cita seu confrade barnabita:

Dom Eliseu não era político, mas sabia que a política podia lhe ajudar no desenvolvimento educativo, econômico e social da terra. Era o instrumento de Deus para realizar o que faltava, e nas mãos da Prelazia tudo dava certo. Nas mãos dos políticos nada crescia; nas mãos da Prelazia tudo se realizava, era natural, pois ninguém de nada se aproveitava $^{59}$.

O que trazemos aqui são fatos que dão possibilidade de se escrever uma história que não se apresenta somente no senso comum, conhecida por muitos, mas que chama a atenção pelo entrelaçamento com as questões de um tempo específico e que marcou, sobremaneira, tantos outros sujeitos ligados a D. Eliseu Coroli, em Bragança, durante uma parte do século XX.

Isso interferiu, sobremodo, nas desconstruções das festas populares e, mais especificamente, na luta pelo controle da cultura ${ }^{60}$, a partir da década de 1930 , observada em amplo acervo documental e que nos levou a notar o quanto ainda é forte, complexa, instigante e quase santificada a memória do bispo Coroli.

IV

Em uma história de vida, é interessante recolher e se deparar com narrativas que privilegiam a memória de um sujeito e o seu relacionamento social, trazendo à tona um o comportamento a partir do passado que o presente não apaga, onde o poder, por exemplo, é legitimado muitas vezes por uma classe.

Essas memórias, recolhidas com esmero, revelam uma riqueza de detalhes que se entrelaçam a outras memórias, sujeitos e histórias. De diferentes meios, pudemos colher experiências de pessoas que compartilham a mesma época e fazem emergir uma visão de mundo diferenciada.

A trajetória do bispo Eliseu Coroli parte do presente para o passado, num movimento ao contrário, de rememoração, o que exige uma interpretação firmada na História Oral, relativizando-se as lembranças, pois como nos sugere Luckacks ao afirmar que "todo historiador trabalha necessariamente baseado em prova incompleta" 61.

Além do Colégio Santa Teresinha, duas outras obras da ação de D. Eliseu Coroli ganharam notoriedade e relevância: a Maternidade Nossa Senhora da Divida Providência e o Hospital Santo Antônio Maria Zaccaria. Segundo sua biógrafa, a Ir. Terezinha Colares, a maternidade surgiu da necessidade de se atender às gestantes que não tinham um suporte necessário para o acompanhamento no trabalho de parto em geral. Em 1945, a falta desse suporte resultou no falecimento da recém-formada professora e ex-aluna de Coroli, Geralda Almeida ${ }^{62}$, fato mais uma vez relacionado à sua influência e ação educativa.

Em 1945, o Cel. Aluízio Ferreira acompanhado do então prefeito Joaquim Lobão da Silveira propuseram a D. Eliseu Coroli a criação de uma maternidade a ser construída com auxílios particulares e do Governo ficando para o patrimônio da Prelazia do Guamá. Com a aceitação do bispo, Ferreira doou o terreno e encaminhou ao bispo cem mil cruzeiros, mil sacas de cimento para a construção e comprometeu-se a angariar outras ofertas para a obra.

No início do ano de 1946, o bispo remeteu ao Departamento Nacional da Criança o projeto da maternidade visando conseguir algum auxílio. No dia 18 de maio daquele ano, 
foi lançada a pedra fundamental da maternidade em homenagem ao aniversário do presidente da República, Gen. Eurico Gaspar Dutra.

Desde 1948, em reunião com seus padres consultores, Eliseu Coroli explicou que a construção da maternidade seria gradativa, conforme a obtenção de verbas e que o já deputado federal Aluízio Ferreira insistiu para que a Prelazia também se encarregasse da construção de um hospital, pleiteando recursos junto ao Governo no orçamento da União.

Eliseu escreveu então um ofício ao Ministério da Educação e Saúde, confirmando o compromisso de construir em Bragança um hospital com 28 leitos, segundo o que recomendava o ministério, porém com o auxílio anteriormente ofertado pelo Governo Federal. Ainda nesse mesmo ano, o contrato para liberação de recursos e construção do prédio foi assinado por Aluízio Ferreira, no ministério, de acordo com a sua solicitação.

A Prelazia se comprometeu em prestar contas da aplicação da verba recebida com a apresentação regular de relatórios e documentos. Porém, em janeiro de 1952, as obras foram paralisadas devido ao corte de parte dos auxílios federais referentes ao ano anterior. Com essa crise, os padres concordaram em colocar em funcionamento os dois prédios destinados à área de saúde sob os cuidados das irmãs Missionárias de Santa Teresinha, de forma provisória, sem contrato ou pagamento algum.

Em julho de 1952, dom Eliseu enviou a Belém para treinamento de enfermagem as irmãs Ângela Rigamonti (prima de seu confrade, Pe. Miguel Giambelli), Amélia Torres e a postulante Antônia Albuquerque. Em outubro de 1952 e de forma precária, iniciaram os trabalhos da maternidade, com a parturiente Jarina Fonseca Pereira, ex-aluna da primeira turma de professoras do Colégio Santa Teresinha, que deu à luz um menino, cujo nome Antônio Maria Fonseca Pereira - foi dado em homenagem a Santo Antônio Maria Zaccaria, fundador dos Barnabitas.

Figura 06: Prédios da Maternidade Nossa Senhora da Divina Providência e do Hospital Santo Antônio Maria Zaccaria, em Bragança, na década de 1950.

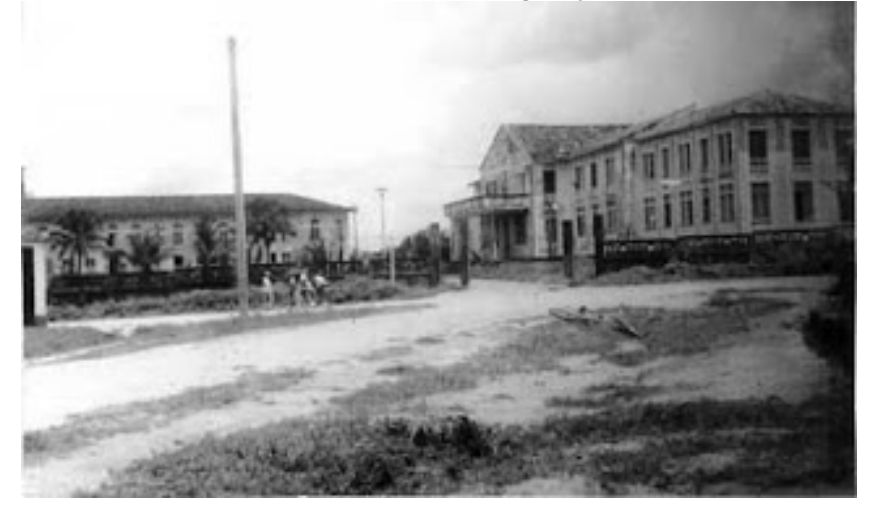

Fonte: Acervo do IBGE (Instituto Brasileiro de Geografia e Estatística).

Sobre alguns desses acontecimentos, notou-se certo silêncio em outras fontes, tais como nos relatos orais acerca de D. Eliseu Coroli ou mesmo em seus registros particulares. Todo esse conjunto de documentos do segmento biográfico, ao lado das memórias, permite a compreensão de como os indivíduos experimentam e interpretam as situações e a vida em sociedade, mas é possível acreditar que realmente tenham ocorrido, mesmo não sendo rememorados no tempo presente por seus contemporâneos, não maculando a imagem do bispo. É importante salientar, ainda, que 
os documentos como alguns já disseram, não falam por si, os historiadores obrigam que eles falem, inclusive, a respeito de seus próprios silêncios. E para realizar tal procedimento, utilizamo-nos de teorias e de procedimentos metodológicos que são, por sua vez, lugares de linguagem, modos de narratividade ${ }^{63}$. (DECCA, 1998, p. 23)

Somente em 06 de novembro de 1952, foram inaugurados a Maternidade e o Hospital, com o objetivo de trabalhar com a saúde em uma área desprovida desses recursos. O primeiro médico do hospital foi Pascoal Pontrandolf, que veio de Belém para trabalhar como clínico e cirurgião, de forma intermitente, sem residir em Bragança.

A partir de 1954, o hospital começou a formar o seu quadro clínico residente na cidade. Em 1955, chegaram à cidade três médicos italianos, Caetano Scalese, Mário Lordi e Alberto. E no dia 19 de março de 1955, dedicado na Igreja Católica a São José, esposo de Maria, foi inaugurado oficialmente o Hospital Santo Antônio Maria Zaccaria.

\section{V}

Nos idos anos de 1960, o Instituto Santa Teresinha já era um estabelecimento consolidado e boa parte dos bragantinos que possuíam condições financeiras ingressava na escola buscando formação intelectual e moral.

Entretanto, os que residiam longe do centro urbano não tinham acesso à Educação, pela ausência de transporte do interior até a cidade diariamente, por dificuldade financeira que impedia a compra de passagens nos meios de transporte disponíveis e pela escassez de tempo devido ao trabalho rural, que normalmente ocupava o dia inteiro.

Nesse cenário, surgiu a ideia de organizar uma emissora de rádio e para concretizar o propósito. Coroli escreveu uma carta aos padres Barnabitas, onde disse que

Com a graça de Deus e a proteção de Nossa Senhora do Rosário, padroeira de nossa Prelazia, estamos prestes a iniciar uma atividade que oferecerá imensas vantagens espirituais e sociais a todos os nossos paroquianos, particularmente aos que moram no interior dos municípios. Falo da Rádio Educadora de Bragança, que provavelmente estará no ar já para o mês de maio, como homenagem filial à mãe de Jesus e nossa ${ }^{64}$.

Através de campanhas de realizadas na Europa, Eliseu Coroli consegue o apoio de inúmeros patrocinadores para o intento do continente, já que participava das reuniões do Concílio Vaticano II. Nesse contexto, surge a figura de um dos seus colaboradores, o Pe. Miguel Maria Giambelli, também sacerdote Barnabita, que se empenhou particularmente para que a Rádio Educadora de Bragança fosse constituída. Equipamentos, treinamentos, legalização burocrática da emissora, ensaios e a vinculação à fé para a resolução de todos os entraves fizeram parte desse cenário, tanto que em 23 de maio de 1960, a emissora entrou em fase experimental, iniciando transmissões ainda não regularmente autorizadas.

Inaugurada em 12 de novembro daquele ano, a rádio transmitiu primeiramente o Círio de Nazaré em Bragança, evento pioneiro na comunicação da região. A entidade contou com os trabalhos de importantes nomes do rádio paraense e se tornou um marco na comunicação de Bragança, por diversos trabalhos, entre eles o educacional e o esportivo. 
Figura 07: Prédio da Fundação Educadora de Comunicação, em Bragança, em 2010.

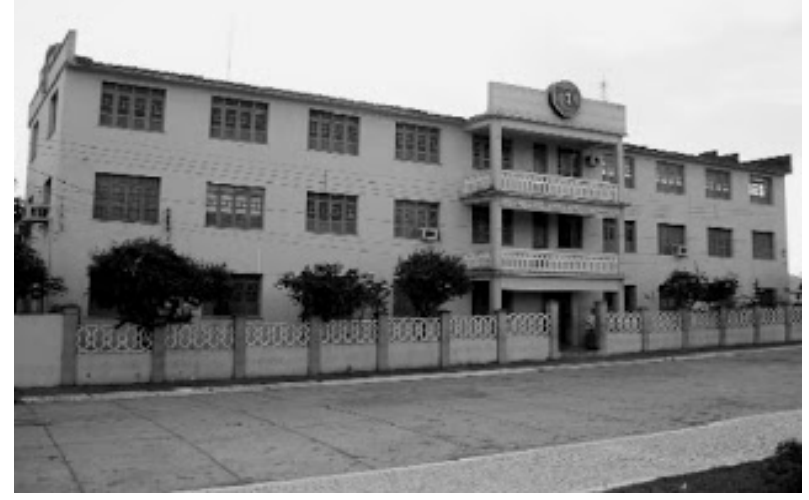

Fonte: Acervo de pesquisa.

A partir da fundação da Rádio Educadora foi acoplado a ela o Sistema Educativo Radiofônico de Bragança (SERB), com a ajuda do Pe. Giambelli, que se tornou seu primeiro diretor. O SERB teve sua origem em 27 de janeiro de 1958, quando os padres da Prelazia do Guamá, numa reunião plenária em que examinaram os vários aspectos do assunto, aprovaram por unanimidade a organização do sistema. Naquela oportunidade foi escolhido o Pe. Miguel Giambelli para coordenar todas as iniciativas necessárias à realização do empreendimento.

Com a fiel colaboração de Giambelli, Eliseu Coroli coordenou os primeiros trabalhos a partir de 1961. Cada paróquia da Prelazia se prontificou a dar uma parte de suas economias para possibilitar a aquisição do equipamento da Rádio Educadora e dos primeiros 150 receptores cativos, destinados às escolas radiofônicas, como se percebe em várias notas dos Livros de Tombo prelatícios da época.

Para conhecer melhor seu novo compromisso, o Pe. Giambelli realizou vários estágios, entre os quais merece um destaque especial o de Natal (RN), onde teve oportunidade para estudar a eficiente organização das rádios-escola pelo então cônego Eugênio Sales.

Em dia 17 de setembro de 1960, o Pe. Miguel compôs a primeira Equipe Central do SERB, a qual se dedicou a organizar cursos para monitores nas várias paróquias da Prelazia. A primeira aula radiofônica ocorreu no dia 17 de abril de 1961, voltada para 1.508 alunos, distribuídos em 107 rádios-postos conectados à Rádio Educadora.

Eliseu Coroli participou, em 21 de março de 1961, juntamente com dom José Távora de Araújo, dom Eugênio Sales e dom Alberto Ramos, da assinatura do Decreto n. ${ }^{\circ}$ 50.370, do presidente Jânio Quadros, que cria o Movimento de Educação de Base MEB $^{65}$. Naquela época, o SERB era o Sistema pioneiro de toda a Amazônia Legal atuando em tele-educação ${ }^{66}$.

No início de 1962, o SERB começou a receber ajuda do MEB, sobretudo com receptores cativos Philips, que nos permitiram ampliar nossa rede de escolas radiofônicas, tanto que, naquele ano, chegamos a ter 362 rádios-postos, com 6200 alunos. Em janeiro de 1965, o Pe. Giambelli deixa a direção executiva do SERB - embora permanecendo presidente jurídico - para transferir-se a Belém como vigário da Basílica de Nazaré, na qual permaneceu até o dia 19 de abril de 1971, data em que reassumiu o cargo no SERB. 
Durante os seis anos em que o Pe. Miguel esteve afastado do SERB, surgiram, na equipe do MEB nacional, elementos políticos e ideológicos contrários aos princípios que norteavam o sistema. As divergências ideológicas foram sentidas, ao ponto de dom Eliseu, no ano de 1970, desligar oficialmente o SERB do MEB "pelo tempo em que continuar na direção do MEB a atual equipe nacional", como disse textualmente o prelado de Bragança, em seu ofício a D. José Távora, Presidente Nacional do MEB.

Órgãos como o Serviço Nacional de Informações (SNI) observou e tratou de implementar um controle maior da programação da rádio verificando se estava fora de algum dos parâmetros estipulados pelo regime militar brasileiro, em especial, críticas à forma de governo ou qualquer manifestação de cunho comunista, práticas e posturas punidas com rigor.

No contexto de luta contra a ditadura, entre os militares e os seus inimigos atrelados à doutrina comunista, é possível entender que a Igreja Católica, em pelo menos dois movimentos - as alas - transitou em lados opostos. Isso acabou por acirrar fortes defesas e demarcar posicionamentos que descambaram em lutas políticas que atualmente entre clérigos e leigos, mesmo tendo alguns destes últimos assumindo a função de diretor do SERB em Bragança, como o renomado professor Raymundo Heraldo Maués, relatado em trabalhos de pesquisa histórica acerca do período ${ }^{67}$.

Em 12 de julho de 1971, o SERB renovou o convênio com o MEB, este sob a presidência de dom Luciano José Cabral Duarte, que proclamou em alto e bom som seguir uma orientação totalmente diferente da administração anterior, a qual causara o desligamento entre os dois segmentos.

Foram mantidos seus 34 funcionários, dentre os quais 19 estavam ligados ao MEB nacional, circunstância que fez do sistema bragantino o legítimo representante do MEB na região, reunindo mais de cem mil alunos em toda a sua história.

Após mai de quarenta anos à frente da Prelazia do Guamá, em 1977, D. Eliseu Coroli finalmente anunciou na Rádio Educadora o seu afastamento, de maneira pungida e reverente. A transmissão, anos mais tarde copilada e disposta em acervo, traz a mensagem do bispo à população bragantina, numa espécie de anúncio de que mesmo sem o vínculo ao poder do cargo de bispo, continuaria no cenário religioso, cultural e social da cidade.

$\mathrm{Na}$ oportunidade, D. Eliseu também registrava a sua indicação recaída do Pe. Miguel Giambelli, também sacerdote Barnabita, para a função de Administrador Apostólico da circunscrição eclesiástica. $\mathrm{O}$ fato repercutiu além das ondas do rádio.

A imprensa na capital relatou a notícia, como se lê abaixo:

Depois de mais de quarenta anos como bispo da Prelazia do Guamá, Dom Eliseu Coroli, entregou ontem, o cargo, ao novo prelado, Monsenhor Miguel Maria Giambelli, recentemente nomeado pelo Papa Paulo VI, em solenidade realizada na Catedral de Bragança, sede da Prelazia, na presença de cinco bispos, mais de duas dezenas de padres e centenas de fiéis, autoridades e políticos que lotaram as dependências do templo na "Pérola do Caeté". ${ }^{68}$

VI

Após uma longa trajetória, que lhe rendeu cansaços e agruras físicas, D. Eliseu Coroli morreu às 16 h30 de uma quinta-feira, dia 29 de julho de $1982^{69}$, na unidade de tratamento intensivo da Clínica SOCOR em Belém (PA), após cinco dias de diversas complicações devido à idade, insuficiência e infecção renal e a parada cardiorrespiratória que lhe ceifou a vida. Junto a seu leito de morte estavam diversas freias de Santa Revista HISTEDBR On-line, Campinas, n.48, p. 93-118 Dez.2012 - ISSN: 1676-2584 110 
Teresinha, congregação por ele fundada em 1948, em especial a sua ex-aluna, Ir. Edith Almeida de Souza, que o acompanhou seus instantes finais.

Muitos de seus alunos, religiosas, bispos, padres colaboradores e amigos estiveram na clínica para verificar o estado de saúde e testemunhas os últimos momentos da vida do bispo Coroli. No hospital, quatro dias antes, recebeu o sacramento da unção dos enfermos das mãos do então Arcebispo coadjutor D. Vicente Joaquim Zico.

Seu corpo foi preparado e colocado numa urna especial ao final da tarde do dia 29 de julho. No caixão, havia desenhos que representavam liras e vários ramos de trigo, símbolos que coincidentemente faziam parte da espiritualidade do bispo Coroli. Às $20 \mathrm{~h} 30$ horas, o carro com seu corpo partiu de Belém em direção a Bragança, percurso de 216 quilômetros e que enfrentou uma chuva torrencial no percurso, segundo os relatos das religiosas Ir. Maria Janete Torres e Ir. Maria do Carmo Mazzoni, pertencentes à congregação missionária organizada por ele.

$\mathrm{Na}$ chegada do ataúde a Bragança, pelas ruas e avenidas uma grande multidão aguardou o carro com o corpo do bispo, aglomerada próximo ao Instituto Santa Teresinha e da Catedral de Nossa Senhora do Rosário, cujos sinos badalavam em tom fúnebre.

Uma sirene da extinta sede do Departamento de Estradas e Rodagens do Pará (DER/PA) em Bragança anunciou a chegada do caixão. Primeiramente, foi levado à capela do colégio para um velório privativo das Irmãs Missionárias de Santa Teresinha, seguidas de centenas de pessoas que prestaram suas homenagens ao bispo falecido.

Enquanto isso, na Rádio Educadora, de meia em meia hora, foi lida a biografia de D. Eliseu, seguida de uma programação fúnebre, como é de costume na emissora. Às 6 horas da manhã do dia 30 de julho de 1982, uma sexta-feira, a primeira missa de corpo presente foi realizada, na capela do Colégio. Em seguida, seu caixão foi levado à Catedral de Nossa Senhora do Rosário, quando D. Miguel Giambelli concelebrou com inúmeros sacerdotes mais uma missa de corpo presente.

Várias celebrações litúrgicas foram feitas na Catedral, uma delas celebrada por D. Alberto Ramos, Arcebispo Metropolitano de Belém (PA). Até as 15h, seu corpo permaneceu no interior da Catedral, sendo levado depois para o Ginásio Santa Teresinha, em mais uma missa presidida por D. Giambelli.

Durante a celebração, foram lidos testemunhos e homenagens pelo Pe. Luciano Brambilla, representando os padres Barnabitas e pela Ir. Oneide Freitas Rotterdam, em nome das Missionárias de Santa Teresinha.

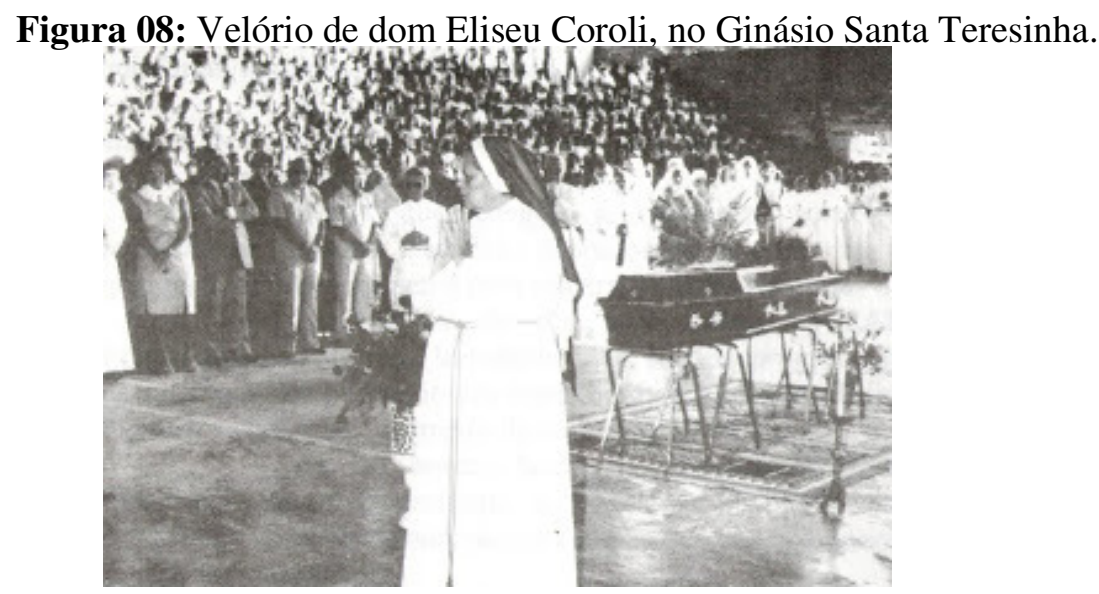

Fonte: O Missionário Feliz, de Terezinha Colares, 1997, p. 345. 
Seu enterro foi realizado em seguida, no local onde foi construída a capela mortuária no interior da Catedral de Nossa Senhora do Rosário, ao lado esquerdo do presbitério e do sacrário, para onde somente religiosas e sacerdotes tiveram acesso.

Em 1994, seu sucessor na administração da já rebatizada Diocese de Bragança do Pará, D. Miguel Giambelli, enviou à Sagrada Congregação da Causa dos Santos, no Vaticano (Roma), alguns escritos, livros e documentários que comprovam a vida de santidade de Eliseu Coroli. Após estudos e análises da sede da Igreja Católica, D. Miguel recebeu a declaração de que poderia ser aberto um processo de canonização do já então declarado Servo de Deus D. Eliseu Maria Coroli.

Em 10 de agosto de 1996, o atual bispo de Bragança D. Luís Ferrando, fez a abertura da fase diocesana do processo de beatificação de D. Eliseu Coroli. Para isso, foi nomeado um tribunal para ouvir testemunhas, analisar escritos, fazer pesquisas sobre a vida e virtudes do bispo italiano. Com o trabalho concluído em 29 de julho de 2004, esses estudos foram encaminhados ao Vaticano. Os textos do processo foram traduzidos para o italiano, recolhidos e organizados em livros com o compromisso da confidencialidade e sigilo e se encontram no Arquivo Coroli, localizado no Instituto Santa Teresinha.

\section{VII}

Em 82 anos de vida, cinquenta e dois deles dedicados à Região Bragantina, Eliseu Coroli construiu o que chamamos de patrimônio Coroli, não só um patrimônio físico, como demonstram imponentes obras por ele fundadas e que beneficiaram a população, mas também um patrimônio espiritual, propósito de sua missão na Amazônia no século XX.

Recordar o passado, recolher esse passado por meio das fontes documentais e da memória e escrever sobre ele não se apresentam tão somente como ações inocentes ao ofício do pesquisador da História. A memória não é algo objetivo, conciso ou que atesta a verdade, mas um objeto a mais na busca pela aproximação entre o presente e o passado. E ela nos vem através, muitas vezes, da oralidade.

Nesse caso, é preciso que o historiador aprenda a considerar os relatos, as pistas do passado dentro da memória, a seleção consciente ou inconsciente desses fatos, a interpretação e a distorção que muitos anos depois se tem dele. Segundo Peter Burke ${ }^{70}$, nos interessamos ou precisamos nos interessar pela memória, considerada como fonte histórica e como fenômeno histórico. Sob o primeiro aspecto, além de estudar a memória como fonte de e para a história, se devem elaborar uma crítica de sua reminiscência, aos moldes da análise de documentos históricos, uma tarefa bem contemporânea.

Nos dois casos, passam a ver o processo de seleção, interpretação e distorção como condicionado, ou pelo menos influenciado, por grupos sociais. Não é obra de indivíduos isolados. (BURKE, 2000, p.69-70).

Ou quando o mesmo Burke nos confirma a relevância da História Oral.

Mesmo os que trabalham com períodos anteriores têm alguma coisa a aprender com o movimento da história oral, pois precisam estar conscientes dos testemunhos e tradições embutidos em muitos registros históricos. (BURKE, 2000, p.72).

Podemos começar a vislumbrar o perfil educador de Eliseu Coroli, que em Bragança queria tão somente ajudar no crescimento do povo que lhe foi confiado, em fé e 
em educação, assim como em outras obras que ele criou nos anos de sua atuação, conseguindo tudo com uma ação política conveniente à época.

Em contraposição à lógica estabelecida por parte significativa da população bragantina, e amparados pelo que escreve Raymundo Heraldo Maués ${ }^{71}$, podemos afirmar que os padres abominaram "a ignorância religiosa" dos caboclos. Atuaram de forma a desmontar e criar outra lógica sobre a cultura popular, conseguindo reforço na autoridade e dominação ideológica educacional e mantendo a sua intervenção, sobretudo no benefício à elite e à classe média bragantina, seja quando edificaram obras e patrimônios físicos, seja quando apresentaram sua proposta de salvação cristã.

Notadamente, este padre Barnabita teve uma presença marcante, pelas obras que empreendeu e no pioneirismo da formação de professores no interior do Pará, sempre com uma base moral cristã e com métodos eficientes para que esta se mesclasse com as intenções de melhoramento em geral das condições de vida da população destes rincões da Amazônia.

Com esta forte e constante carga espiritual, Eliseu Coroli, um homem místico, mas também um líder religioso criou obras de apostolado em prol das necessidades mais evidentes do período entre as décadas de 30 e 60 em Bragança. Fala-se hoje de suas obras como exemplo de virtuosismo de sua experiência como padre, bispo e administrador apostólico da imensa extensão territorial da extinta Prelazia do Guamá, hoje Diocese de Bragança. Todo esse cuidado e a manutenção de um controle ideológico sobre sua obra educacional, não somente a do Instituto Santa Teresinha, foram eficazes para a sua permanência no território nacional, num tempo em que poderia sofrer as perseguições do Estado varguista.

No caso de estudos sobre História e Educação, a diversificação das fontes ${ }^{72}$ para analisar e interpretar o objeto trouxe contribuições significativas para o resultado desse artigo, e a partir de uma maior abrangência de espaços de análise metodológica, é possível construir um conhecimento mais próximo à realidade estudada.

Chama a atenção também a visita de meia hora concedida a ele pelo Papa Paulo VI, de 6 de fevereiro de 1975, na qual D. Eliseu Coroli relatou a alegria de ser missionário, o que o próprio pontífice fez questão de realçar, como segue.

$\mathrm{Na}$ quarta-feira seguinte, dia de cinzas, num sermão quaresmal na Basílica de São Pedro, Paulo VI referiu-se ao pensamento que o nosso bispo the havia ilustrado, publicado depois no L'Osservatore Romano: 'Um missionário, que nestes dias, veio visitar-Nos, falava-Nos dos resultados felizes de uma iniciativa, seu intitulado Apostolado da Alegria. Porventura não é esta uma autêntica e sapiente interpretação do Evangelho, mensagem da boa nova? (BARNABITAS NO BRASIL, 2003. p. 101).

Encontramos todo esse conjunto de sentimentos nos votos da congregação criada por ele, com ênfase ao chamado Apostolado da Alegria, já que D. Eliseu desenvolvia um trabalho pedagógico pautado na alegria, no prazer e bem-estar, o que era fundamento de sua espiritualidade desde a juventude, tanto que "no seu emblema episcopal quis o lema: 'Filhinhos paz e alegria' e nas suas cartas apareciam sempre jaculatórias ${ }^{73}$ e invocações a Jesus, Maria e José: alegria, amor e vida ${ }^{74,}$.

Como enfatizou o também o bispo D. Andrea Maria Erba, de Velletri, de Segni (Itália), a dedicação de Eliseu às crianças e o afeto especial às famílias, obtiveram como lucro uma educação segura, controlada e altiva. Tal afirmação se apoiou nas obras de Eliseu como missionário na Região Bragantina, como bem o faz no Jornal L'Osservatore 
Romano, à página 4, da edição italiana do dia 9 de fevereiro de 2000, data em que Eliseu Coroli completaria seu centésimo aniversário.

Assim, ao analisar D. Eliseu Coroli, não se pode separar o religioso do administrador, por sua escolha de ver na escola uma família, fato demonstrado nos documentos e regulamentos que escreveu e, em especial, ao fato de chamar todos os alunos, indistintamente, de "minhas crianças", expressão carinhosa que perdurou por toda a sua trajetória, até os últimos dias de sua vida ${ }^{75}$.

Evidentemente, para dar resposta a certas lacunas da História, como as aqui levantadas, há que se atentar ao que nos dizem os documentos biográficos, assim como às memórias e registros pessoais, que não podem ser considerados como reflexos passivos de uma personalidade individual, isolada, mas numa leitura da própria realidade social experimentada. Nesse sentido, uma orientação é cabível.

Apesar da impossibilidade de se recuperar muitos acontecimentos, experiências e vivências do ser humano, também temos que convir que desde os tempos imemoriais os homens produziram (e ainda produzem) artefatos, documentos, testemunhos, monumentos, entre outros, que tornam possível o entendimento do homem sobre sua própria trajetória. São exatamente esses registros históricos que constituem os documentos, os testemunhos, os monumentos usados pelo historiador para se aproximar e tornar inteligível seu objeto de estudo. ${ }^{76}$

Nessa abordagem, não nos deparamos somente com impressões favoráveis em relação a D. Eliseu Coroli, como o comentário encontrado no jornal intitulado Matuto Ilustrado, feita por um contemporâneo da década de 1940, assinado com o pseudônimo de Thomaz de Aquino, uma opinião sobre a atuação dos padres e que se choca com diversos pensamentos e afirmações que se tornaram hegemônicas em favor desses religiosos.

(...) Negar que os padres Barnabitas trouxeram um novo surto de progresso intelectual às novas gerações e em rasgos de uma ousadia dinâmica que ultrapassa as raias do heró́smo, terem levantado construções que são outros muitos tantos templos majestosos e imponentes, elevando Bragança ao nível de cidade moderna, seria decair na mais vil degradação para justificar a opinião, de espíritos de contradição aferrados a suas idéias retrogradas e incongruentes..." (No Patal, 14.11.1949) ${ }^{77}$.

Tal assertiva se contrasta, por exemplo, com as veementes defesas em favor de Eliseu Coroli, como a do cronista, escritor e ex-prefeito Benedito Cezar Pereira, autor da Sinopse da História de Bragança ${ }^{78}$, quando é citado por D. Miguel por uma de suas afirmações a favor de Coroli, quando diz que cerca de uma dúzia de bragantinos tentou enganar "nossos caboclos inocentes e de boa fé", na propalada questão entre a Prelazia do Guamá e a Irmandade do Glorioso São Benedito de Bragança (IGSBB), o que resultou num certo afastamento do já bispo emérito de eventos sociais e culturais em Bragança.

Dom Eliseu é ainda lembrado pela imagem de um educador que exigia, vigiava, ditava regras metódicas, mas que era maleável e sensível em algumas oportunidades, não alterava a voz, não brigava, mas levava à reflexão, ao aconselhamento a quem educava com doçura e mansidão pois,

Que conheçam e amem realmente nosso Senhor Jesus Cristo e a Virgem Maria e aos que assim alcancem a salvação eterna. O que nos interessa é 
exatamente isto! (...) Doçura não é fazer todos os caprichos da criança... Consiste na paz revestida de bondade, de compaixão, de desculpa, de perdão. Consiste na calma, no domínio de si mesmo; consiste nas palavras apropriadas. Consiste no modo delicado... No sorriso sobrenatural. Consiste sobre tudo no amor que dedicamos à criança, por amor a nosso Senhor Jesus Cristo. A paciência é estátua fria, calada, não castiga também não acaricia, não repreende também não anima. A doçura é "bom humor" constante: sempre sereno e sempre alegre. ${ }^{80}$

Isso, por fim, acabou abrindo espaço para a afirmação, em nossa região, de um modelo de administração eclesial e educacional, que o tornaria um símbolo para uma época, num mosaico muito bem construído e que atendeu aos apelos que a Educação necessitava nas terras de missão no início do século XX e que, no imaginário popular, seria o grande benfeitor da sociedade bragantina.

E a história de sua atuação não só atestou seu empreendedorismo, como abalizou o seu cuidado com a religiosidade e com o preparo de professores e catequistas, somado a um desejo profundo de ver, em Bragança, uma geração apta ao trabalho, ciosa no respeito às regras eclesiásticas e de uma sociedade formada na Educação e na obediência religiosa.

\footnotetext{
Notas

${ }^{1}$ Licenciado Pleno e Bacharel em História pela Universidade Federal do Pará, 2002. Mestre em História pela Universidade Federal do Pará, 2006. Professor da Faculdade de História da Universidade Federal do Pará, no Campus Universitário de Bragança.

2 Licenciada Plena em Pedagogia pela Universidade Federal do Pará, 2004. Coordenadora Técnica e Pedagógica da Secretaria Municipal de Educação, em Bragança.

${ }^{3}$ Licenciado Pleno em História pela Universidade Federal do Pará, 2011. Professor no Instituto Santa Teresinha, em Bragança.

${ }^{4}$ Conforme carta de apresentação de Ângelo Amendola, diácono permanente da Diocese de Villetri, Segni (Itália) aos escritos traduzidos pelos Padres Barnabitas e que estão contidos no Arquivo Coroli, de posse das Irmãs Missionárias de Santa Teresinha, alguns deles dispostos à pesquisa.

${ }^{5}$ Segundo CERTEAU, M. A escrita da História. 2. ed. Rio de Janeiro: Forense Universitária, 2002. p. 16.

${ }^{6}$ Este trabalho com o conceito de memória está presente em POLLAK, Michael. "Memória, esquecimento e silêncio". In: Estudos Históricos, Rio de Janeiro, vol. 2, n.3, 3-15, 1989; e em "Memória e Identidade Social" In: Estudos Históricos, Rio de Janeiro, vol.5, n.10, 1992, pp. 200-212.

${ }^{7}$ Conforme COLARES, T. O Missionário Feliz. Paragominas: Gráfica e Editora São Marcos, 1997. p. 12.

${ }^{8}$ Congregação religiosa e missionária fundada por Santo Antônio Maria Zaccaria e inspirada na obra do missionário São Paulo, conhecida pela sigla CRSP - Clérigos Regulares de São Paulo.

${ }^{9}$ Eliseu Coroli produziu durante sua vida inúmeros excertos no que se conhece atualmente por Caderno de Anotações. O número 24 dessas anotações traz o conteúdo de "O Meu Vittorino", texto já traduzido para o português, trazendo experiências por ele vividas naquela escola. Nesses escritos, Coroli relembrou com detalhes os nomes e lugares da escola, enfatizou diversas peculiaridades dentre as quais a alegria da formação dos alunos, a rigidez da disciplina e o forte apelo à conduta moral. O próprio Eliseu nunca tornou públicas suas anotações pessoais, o que só foi conhecido após a sua morte e, mais precisamente, durante o processo que estuda a possibilidade de sua beatificação pela Igreja Católica. Essas anotações foram encontradas e dispostas a partir do Arquivo da Cúria Generalíssima dos Barnabitas em Roma, Itália.

10 Vittorino da Feltre, conhecido também por Rambaldoni foi um humanista, religioso e professor da Universidade de Pádua, que se destacou na Educação com o trabalho de ser o preceptor dos filhos da família dos Gonzaga, em Mântua (Itália). A contribuição de Feltre na Educação se concentra na reunião de ideais humanistas e cristãos na educação de jovens da cidade de Pádua, na chamada Casa Giocosa, ambiente de educação integral, de formação moral e intelectual, com a apropriação de conhecimentos mais relacionados ao domínio cognitivo e desenvolvimento do corpo. Conforme sintetiza PÉREZ, N. G. Mujeres y Mecenas. Murcia: Universidad de Murcia, 2003.

${ }^{11}$ Conforme MANACORDA, M. A. História da Educação. 12. ed. São Paulo: Cortez, 2006.
} 
${ }^{12}$ Parte dessas acepções pedagógicas deste artigo se encontram em OLETO, Leila do S. R. Eliseu Coroli, o educador de educadores: perspectivas educacionais pioneiras de influência barnabítica na Região Bragantina, no início do século XX. (Monografia). Curso de Licenciatura Plena em Pedagogia. Bragança: Universidade Federal do Pará, 2004.

${ }^{13}$ Esta obra creditada a Santa Teresinha do Menino Jesus foi recolhida por Irmã Genoveva da Santa Face (Celine Martin), sua irmã e colega de convento. Nela se encontram pensamento e conselhos de vida religiosa. A obra está disponível na edição SANTA TERESINHA DO MENINO JESUS. Conselhos e Lembranças. Recolhidos por Ir. Genoveva da Santa Face. 3. ed. São Paulo: Edições Paulinas, 1987.

${ }^{14}$ Francisca Teresa Martin, santa católica, nascida na França em 1873, foi uma religiosa pertencente à Congregação das Carmelitas descalças, do Carmelo de Lisieux, mundialmente venerada e conhecida pelos ensinamentos dispostos em seus manuscritos autobiográficos, organizados e reunidos por sua irmã Agnes (Inês) Martin, também religiosa daquela congregação, na obra denominada História de uma alma. Faleceu aos 24 anos em 1897. É umas das santas doutora da Igreja.

${ }^{15}$ Todos os cadernos de anotações pessoais de D. Eliseu Maria Coroli se encontram no Arquivo Coroli, de posse das Irmãs Missionárias de Santa Teresinha, cuidadosamente conservados e analisados em vista do Processo de Beatificação e Canonização deste religioso perante a Igreja Católica.

${ }^{16} \mathrm{Cf}$. idem.

${ }^{17}$ Cf. COLARES, op. cit. 97.

${ }^{18}$ Conforme BARNABITAS no Brasil 100 Anos. Belém, SOBRAC - Sociedade Brasiliense de Ação e Cultura (Província dos Barnabitas do Norte). Agência Ver Editora, 2003.

${ }^{19}$ José Meireles Sisnando, um dos alunos de Pe. Eliseu Coroli na Escola Apostólica de Jacarepaguá, no Rio de Janeiro, tem depoimento escrito e citado em COLARES, Terezinha. O Missionário Feliz. Paragominas: Gráfica e Editora São Marcos, 1997.

${ }^{20}$ Prelazia: tutela de uma congregação.

${ }^{21}$ Registro feito pelo Pe. Eliseu Coroli nas notas históricas da Prelazia do Guamá sobre a região.

${ }^{22}$ Impressões colhidas conforme Tradução dos Escritos de D. Eliseu, 2001. Arquivo Coroli. p. 34.

${ }^{23}$ Conforme nos relata o Pe.Barnabita José Maria Ramos das Mercês no Jornal Voz de Nazaré, na matéria Barnabitas 450 anos. Belém, 22 jan. 1984. Artigo, p. 3.

${ }^{24}$ O ALPHABETO e a palavra de Deus nas selvas brasileiras. Jornal A Tarde, Rio de Janeiro, 22 ago. 1939. Artigo p. 7.

${ }^{25}$ Cf. MERCÊS, op. cit. p. 3.

${ }^{26}$ Movimento de reforma católica no século XIX, que tinha como pressupostos básicos a adequação do catolicismo brasileiro ao Concílio de Trento e sob as orientações de Roma.

${ }^{27}$ No que se refere ao conceito de cultura, afirma Thompson: "não podemos esquecer que 'cultura' é um termo emaranhado, que, ao reunir tantas atividades e atributos em um só feixe, pode na verdade confundir ou ocultar distinções que precisam ser feitas. Será necessário desfazer o feixe e examinar com mais cuidado os seus componentes: ritos, modos simbólicos, os atributos culturais da hegemonia, a transmissão do costume sob formas específicas das relações sociais e de trabalho". THOMPSON, E. P. Costumes em comum. Estudos sobre a cultura popular tradicional. São Paulo: Companhia das Letras, 1998. p.22.

${ }^{28}$ Cf. LE GOFF, J. História e memória. 2. ed. Campinas: UNICAMP. 1992. p. 51.

${ }^{29}$ Cf. THOMPSON, E. P. Costumes em comum. Estudos sobre a cultura popular tradicional. São Paulo: Companhia das Letras, 1998. p. 17

${ }^{30}$ Cf. COLARES, Terezinha. op. cit. 1997.

${ }^{31}$ Nova denominação da Prelazia do Gurupi. Fonte pesquisada no arquivo da Cúria Diocesana de Bragança. Livro de tombo nº 1, 1930-1946. p. 12. Hoje é a Diocese de Bragança do Pará.

${ }^{32} \mathrm{Na}$ p. 27, do Livro de Tombo da Diocese de Bragança, n. ${ }^{\circ} 1$ (1930-1946), encontra-se o histórico sobre a vinda destas Irmãs com todos os pormenores desde a visita à Casa Geral, em Monza, na Itália.

${ }^{33}$ Cf. BURKE, P. (org.). A escrita da história: novas perspectivas. São Paulo: Editora Universidade Estadual Paulista, 1992. p. 164.

${ }^{34}$ JORNAL VOZ DE NAZARÉ. Arquidiocese de Belém. Edição de 22 de janeiro de 1984. p. 3.

35 Como por exemplo, o livro BORDALlO DA SILVA, A. Contribuição ao Estudo do Folclore Amazônico na Zona Bragantina. Belém: Falângola Editora, 1981.

${ }^{36}$ São interessantes as preocupações de Raymundo Heraldo Maués, em seu livro Padres Pajés, Santo e Festas (1995), citando Geertz sobre etnografia, como "uma descrição interpretativa do 'fluxo do discurso social', procurando preservá-lo e 'fixá-lo em formas pesquisáveis'; na maior parte é, também, uma descrição 'microscópica'”. In: GEERTZ, C. A Interpretação das Culturas. Rio de Janeiro: Jorge Zahar, 1978. p.31.

${ }^{37}$ Notícia colhida do jornal O Caeté, ano IV, ${ }^{\circ}$ 2, de 10 de janeiro de 1904, que registra o falecimento do cônego Miguel Joaquim Fernandes, na comunidade do Almoço, zona rural de Bragança (PA).

Revista HISTEDBR On-line, Campinas, n.48, p. 93-118 Dez.2012 - ISSN: 1676-2584 
${ }^{38}$ Conforme informações colhidas em diversas entrevistas com as Irmãs Missionárias de Santa Teresinha, em pesquisas entre os anos de 2008 e 2009.

39 A Escola Normal do Pará, hoje Instituto de Educação Estadual do Pará, foi criada pela Lei n. ${ }^{\circ}$ 669, sancionada pelo Presidente da Província do Pará, Joaquim Machado Portela. Instalada em 13 de maio de 1871, funcionava numa dependência do Colégio Nossa Senhora do Amparo, no Liceu Paraense, hoje Colégio Paes de Carvalho.

${ }^{40}$ Conforme relatos orais da Ir. Janete Torres, missionária de Santa Teresinha, secretária do processo de beatificação de D. Eliseu Coroli e responsável pela guarda dos documentos do Arquivo Coroli.

${ }^{41}$ Conforme a carta do Pe. Eliseu Coroli destinada às famílias bragantinas, de 26 de novembro de 1938.

${ }^{42}$ Conforme tradução dos escritos de D. Eliseu, 2001. Arquivo Coroli. p. 44.

${ }^{43}$ Retirado de Os Cinqüenta Anos do Instituto Santa Teresinha. Bragança, 1988. p. 3.

${ }^{44}$ Livro de Tombo da Diocese de Bragança, n. ${ }^{\circ} 1$ (1930-1946). p. 41.

${ }^{45}$ Cf. COLARES, op. cit. p. 125.

${ }^{46}$ Conforme informações colhidas em diversas entrevistas com as Irmãs Missionárias de Santa Teresinha, em pesquisas entre os anos de 2008 e 2009.

${ }^{47}$ Constituições Diocesanas das Províncias Meridionais do Brasil, 1915. Artigo 1175, pp. 257-278.

48 JORNAL O BRAGANTINO. "Uma data memorável para os bragantinos. 5 de julho - Lançamento da Pedra do Colégio Santa Teresinha - As Solenidades - Entusiasmo e Regozijo - Teatro de amadores". Bragança, 14 jul. 1940. n. 97. Artigo p. 1.

${ }^{49}$ Conforme tradução dos escritos de D. Eliseu, 2001. Arquivo Coroli. p. 49.

${ }^{50}$ Segundo OLETO, op. cit. p. 39.

${ }^{51}$ Para Stuart Hall, a noção de identidade está relacionada com "pessoas que se parecem", "sentem a mesma coisa" ou "chamam a si mesmas pelo nome", como referencial, mesmo que não satisfazem totalmente os pressupostos de sua compreensão. Desta forma, "a identidade é sempre vista da perspectiva do outro". Conforme HALL, S.. "Old and new identities, old and new ethnicities". In: KING, A. D. (ed.). Culture globalization and the world-system. Londres, LacMilan, Nova York: State University of New York, 1993.

${ }^{52}$ Observações a partir da visita ao Instituto Santa Teresinha, onde se encontram esses quadros.

${ }^{53}$ Segundo análises a partir de Bourdieu, a cultura dominante pressupõe a imposição de valores sobre as demais culturas, mediada por conflitos simbólicos, já que o instrumento desses conflitos é a "injunção da definição legítima do mundo social", tornando-o o arbítrio cultural de uma classe em cultura legítima. Cf. BOURDIEU, P. O Poder simbólico. Rio de Janeiro: Bertrand Brasil, 2000. p. 61ss.

${ }^{54}$ Conforme relatos orais colhidos em entrevista com a Ir. Janete Torres, missionária de Santa Teresinha, secretária do processo de beatificação de D. Eliseu Coroli e responsável pela guarda dos documentos do Arquivo Coroli, em agosto de 2008.

55 Outro prédio tomado pelo $35^{\circ}$ Batalhão de Caçadores foi o a do Grupo Escolar Monsenhor Mâncio Ribeiro, em Bragança, conforme relatos em entrevistas com diversos bragantinos.

${ }^{56}$ Livro de Tombo da Diocese de Bragança, n. ${ }^{\circ} 1$.

${ }^{57}$ Cf. COLARES, op. cit. p. $85 \mathrm{ss}$.

${ }^{58}$ BORDALLO DA SILVA, B. Cronologia Bragantina: um capítulo na História da Amazônia. Inédito. Bragança: 1954.

${ }^{59}$ Cf. BRAMBILLA, Luciano; MEIRELES, Vera M. de B.; SILVA, Leida A. da. Vocação. s.e. Belém, 2003. p. 26.

${ }^{60}$ Para mais informações acerca dessas estratégias pelo controle da cultura, em particular, a relacionada às manifestações do culto ligado a São Benedito, ver NONATO DA SILVA, Dário B. R. Os Donos de São Benedito: convenções e rebeldias na luta entre o catolicismo tradicional e devocional na cultura de Bragança, século XX. (Dissertação) Mestrado em História Social da Amazônia. Belém: Universidade Federal do Pará, 2006.

${ }^{61}$ LUKACS, John. O Hitler da História. Rio de Janeiro, Jorge Zahar, 1998. p.19.

${ }^{62}$ Segundo nos apresenta OLIVEIRA, Romyel D. C. de. Dom Eliseu e a revolução da Educação bragantina durante o século XX. (Monografia). Curso de Licenciatura Plena em História. Belém: Universidade Federal do Pará, 2010.

${ }^{63}$ DECCA, Edgar S. de. "Questões teórico-metodológicas da História”. In: SAVIANI, D.; LOMBARDI, J. C.; SANFELICE, J. L. (org.). História e História da Educação. Campinas, SP: Autores Associados, 1998.

${ }^{64}$ Carta Circular, de 24 de fevereiro de 1960. Livro de Tombo da Diocese de Bragança, n. ${ }^{\circ} 6$.

${ }^{65}$ O Movimento Educacional de Base (MEB) foi criado pela Conferência Nacional dos Bispos do Brasil (CNBB), em 1961, com o objetivo de "desenvolver um programa de Educação de Base por meio de escolas radiofônicas, nos estados do Norte, Nordeste e Centro-Oeste do país. Sua criação foi prestigiada pela Presidência da República e sua execução apoiada por vários ministérios e órgãos federais e estaduais,

Revista HISTEDBR On-line, Campinas, n.48, p. 93-118 Dez.2012 - ISSN: 1676-2584 
mediante financiamento e cessão de funcionários. Foi prevista também importante colaboração do Ministério de Viação e Obras Públicas, à época responsável pela concessão dos canais de radiodifusão, visando agilizar os processos de criação e ampliação de emissoras católicas". Para mais informações, consultar FÁVERO, Osmar. Uma pedagogia da participação popular; análise da prática pedagógica do MEB - Movimento de Educação de Base, 1961-1966. Campinas: Autores Associados, 2006.

${ }^{66}$ Cf. OLIVEIRA, op.cit. p.59.

${ }^{67}$ Como no trabalho da religiosa SILVA. Francisca P. A História continua na arte de educar nas terras dos Caetés. (Monografia). (Monografia). Curso de Licenciatura e Bacharelado em História. Bragança: Universidade Federal do Pará, 1994.

${ }^{68}$ Conforme o jornal O Liberal, na edição de 24 de abril de 1977.

${ }^{69}$ Segundo dados retirados a partir de um detalhado relato em COLARES, op. cit. pp. 338-349.

${ }^{70}$ Cf. BURKE, P. "História como memória social". In: Variedades de história cultural. Rio de Janeiro: Civilização Brasileira. 2000, pp. 67-89.

${ }^{71}$ Cf. MAUÉS, R. H. Uma outra “invenção" da Amazônia: religiões, histórias, identidades. Belém: CEJUP, 1999.

${ }^{72}$ ARAÚJO, José C. S., GATTI JÚNIOR, D. Novos temas em História da Educação brasileira. Campinas (SP): Autores Associados, 2002.

${ }_{73}^{73}$ Jaculatória: frase, palavra religiosa, indulgência.

${ }^{74}$ Conforme textos extraídos dos arquivos da Cúria Generalíssima dos Padres Barnabitas em Roma, Itália.

${ }^{75}$ Impressões colhidas em entrevistas orais a respeito do comportamento de Eliseu Coroli, no decorrer da pesquisa, em visita ao Arquivo Coroli e arquivo particular da Secretaria do Instituto Santa Teresinha. Segundo seus contemporâneos, esta expressão própria do bispo vinha acompanhada pelo gesto, também particular, de "esfregar as mãos" enquanto conversava.

${ }^{76}$ LOMBARDI, J. C.; NASCIMENTO, M. I. M. (org.). Fontes, história e historiografia da educação. Campinas: Autores Associados, 2004. p. 156.

${ }^{77}$ Jornal do Caeté, 20.11.1949, n. ${ }^{\circ}$ 180, In: SILVA, D. B. da. Os Tambores da Esperança: um estudo antropológico sobre a construção da identidade na Irmandade do Glorioso São Benedito de Bragança. Belém: Falângola Editora, 1997. p. 42.

${ }^{78}$ PEREIRA, Benedito C. Sinopse da História de Bragança. Belém: Imprensa Oficial, 1963.

${ }^{79}$ GIAMBELLI, M. Notícias históricas a respeito do processo contra a Irmandade Civil de São Benedito. s/e. Bragança, 07.out.1986. mimeo.

${ }^{80}$ Cadernos manuscritos de instruções de Eliseu Coroli, destinado às Irmãs ou às futuras professoras. Arquivo Coroli, retirado de ROCHA, Aldo F. da. Contributo de Dom Eliseu Maria Coroli para o Sistema Educacional em Bragança-PA. (Monografia). Curso de Graduação em Ciências da Religião. Belém: Universidade Estadual Vale do Acaraú, 2003. p. 42

Recebido em novembro/2012

Aprovado em dezembro/2012 